Journal of the Scholarship of Teaching and Learning, Vol. 21, No. 4, December 2021, pp. 214-224. doi: 10.14434/josotl.v21i4.32844

\title{
Reflections on Teaching Against White Supremacy During a Time of Social Rupture and Transformation
}

\author{
Erica Fonseca and Stéphanie Wahab
}

Portland State University

\begin{abstract}
Social Justice and Social Work is a foundational course required for all social work students in the master's of social work program at Portland State University. Although the course has long focused on interrupting oppressions including White supremacy, teaching the course during the fall of 2020 required a nimble dance between our familiar modes of teaching and the need for spontaneous adaptation and creativity. The unique landscape for this course included teaching the course remotely (Zoom), inside a university embattled around the arming of its security force (that killed a Black man in 2018), in a city targeted by an armed federal response to the racial uprising led by Black Lives Matter, in a state with a long history of White supremacy and Black exclusion, and under a federal administration explicitly aligned with White supremacy. This paper offers a reflection of our teaching about and against White supremacy during this unique moment in time. We position our writing at the intersections of teaching and activism, of hope and uncertainty. It is from our shared commitment to the abolishment of White supremacy that the following tenets were derived, grounding our experimental teaching in complexity, complicity, and social transformation: (1) remembering for the future, (2) attending to collective grief and rage, (3) bringing the streets (racial uprising) into the classroom, and (4) repurposing the classroom for social transformation.
\end{abstract}

Keywords: George Floyd uprisings, Portland protests, White supremacy, reflexivity, praxis.

You have to act as if it were possible to radically transform the world. And you have to do it all the time.

-Angela Davis, lecture, Southern Illinois University

The year 2020 was one of rupture without a blueprint. People living in the United States were thrust into a confrontation with the loss of normalcy, a "normalcy" supported by violence, colonial legacies, Black death, deep wealth, and racial inequities. The disparate and connected uprisings throughout the country forced us to think critically and honestly about what it takes not only to confront racism but also to work to abolish White supremacy in and out of the classroom. The George Floyd uprisings facilitated moments of connection and anger, destruction, and creation, all of which became a backdrop for our teaching during the fall of 2020. In this reflective essay, we describe our experiences teaching a social justice course for social work students at Portland State University during this extraordinarily tumultuous and chaotic time in the history of both Oregon and the United States.

We write from distinct subjectivities, with different relationships to White supremacy and settler colonialism, different ages, different positional status within the University, and different political commitments. One of us identifies as U.S. born, White, and of Western European descent, and the other as an immigrant and Palestinian-French Canadian. We are both invested in intersectional, queer, and poststructural theories. While there is no doubt our lived and queer subjectivities shape how we learn and teach, so too do our ideological, epistemological, and political groundings. We understand White supremacy as a structural, institutional, individual, historical, contemporary, discursive, and personal phenomenon that is fundamentally genocidal for Black, Indigenous, and people of color (BIPOC) communities, advantageous to the continuation of 
neoliberal ideologies/capitalism, and integral to the maintenance of authoritarian hierarchies. We understand White supremacist ideologies as foundational to, among other things, police terror, imperial wars, xenophobia, hetero/cissexism, and classism. As non-Black instructors, we strive to take nothing for granted about how White supremacy moves through White/non-Black bodies, our own included. We recognize the complicated entanglements we have with White supremacy as a White person and a non-Black person of color.

What follows are reflections on how we navigated teaching about and against White supremacy during the pandemic and racial uprising of 2020. We wish to highlight how theory, and perhaps more importantly, praxis served as a life vest during this critical moment of crisis and transformation. Critical pedagogies shaped our teaching practices as we strove to share power and to trouble oppressive techniques of governance in the classroom. Although teaching during that moment in time, in a city and state battling with local police and federal officers in the streets, filled us with uncertainty, excitement, grief, frustration, love, and rage, it left us with experiences of hope and insights we intend to carry forward.

\section{The Course: Social Work and Social Justice}

The class at the center of our reflections is designed as an introductory social justice course for 1styear social work students in the master's in social work program in the School of Social Work and is required during the first term of the program. This course examines epistemological and theoretical approaches to understanding social justice and equity as they relate to erasure, oppression, marginalization, and exclusion. Although ambitious, the course aims to explore intersecting forces and structures of domination, including but not limited to imperialism and colonization; poverty and classism; racism and Whiteness; citizenship and statelessness; anti-Semitism and Islamophobia; sexism, heterosexism, and cissexism; and ableism and disability. This course aims to challenge social work students to consider how their social work knowledge and practices are both complicit in these systems and deepen their understanding of how they might strive to resist and transform these systems in service of equity and liberation. Although the course is more heavily weighted toward learning and exploring than applying or practicing, the sociopolitical landscape provided opportunities for the students to apply what they were learning to the activism in the streets and for us to weave the activism in the streets into the classroom.

\section{Social, Political, and Spatial Context}

Oregon was founded as a state explicitly to uphold the supremacy of Whiteness (Semuels, 2016). The Oregon state constitution of 1857 stated:

No free Negro, or Mulatto, not residing in this state at the time of the adoption of this constitution, shall come, reside, or be within this state, or hold any real estate, or make any contracts, or maintain any suit therein. (Oregon State Archives, n.d.).

As instructors in Portland, Oregon, we are teaching within the living legacy of Oregon's Black exclusion laws and the ongoing displacement of Black people via relentless gentrification (Burke \& Jeffries, 2016). Although Black exclusion is certainly not unique to Oregon, it is crucial to note that Oregon is the only state that codified its racist exclusion through a series of laws throughout the 19th and early 20th centuries (McClinktock, 1995; Semuels, 2016). The brutal exclusion of Black people manifested in myriad forms, ranging from the vicious Lash Law that mandated 39 lashes, every six months, until the Black person left the state (Brown, 1892), to the omnipresent threat and realization

Journal of the Scholarship of Teaching and Learning, Vol. 21, No. 4, December 2021. josotl.indiana.edu 
of extrajudicial lynchings (though they were often supported by local law enforcement; Imarisha, 2020). Moreover, much of the racist discourse, foundational to the state, remained in its constitution into the 21st century (Imarisha, 2020).

A consequence of this White supremacist history is that Oregon became a haven for fascists and neo-Nazi groups, with Portland deemed "Skinhead City" throughout the 1990s (Vercammen \& Yan, 2017). Moreover, Portland's majority White population makes it continually seductive to White supremacists interested in realizing the White utopian goals of the settlers who came before them (Michel, 2017). Portland continues to be recognized as one of the Whitest cities in the United States, with White Americans making up 77.3\% of its population (United States Census Bureau, 2020).

Although profoundly racist histories contextualize Oregon, Portland sustains a long legacy of antiracist activism and social unrest (Burke \& Jeffries, 2016). Over the last 60 years, the Portland chapter of the Black Panther Party, The Black Justice Committee, Portland Community Liberation Front, Rose City Antifa, the Western State Center, and many other leftist groups have organized for racial justice and police accountability and have built alternative infrastructures for resistance within Portland's city limits (Darby et al., 2015). Consequently, Portland was in some ways primed for the racial uprising that manifested after the death of George Floyd as the city experienced 100 consecutive days of protest, primarily led by Black Lives Matter (BLM), against police brutality and institutional racism (Wilson, 2020). Also noteworthy and relevant to our classroom experiences is that the uprising was coupled with a substantial federal and local law enforcement crackdown on the protests during the summer and fall of 2020.

Demonstrations occurred nightly from May to September 2020 in various sections of the city. The Justice Center was one of the hubs of the movement for Black lives. It became a nightly gathering place to share food, strategize, stand off with federal agents, form affinity groups, lend medical aid, dance, fight off tear gas, tear down fences-metaphorically and actually — and move with others committed to the eradication of White supremacy. Routine and indiscriminate tear gassings of protesters made it impossible to stay in one place, catalyzing impromptu marches throughout the downtown city terrain. Leading these marches were Black people and other people of color, often young, some appearing to be in their teens. It was a moment in time where rage against White supremacist terror and the desire for liberation were displayed in equal measure.

\section{The Classroom Context}

We suspect that the images of the uprising for racial justice will soon be documented in the history books as a moment in which Black people and countless supporters took a regional and national stand against White supremacy, as White nationalists organized and mounted a resistance to these protests in Oregon (Brulliard et al., 2020). Not surprisingly, the images and narratives of multiethnic solidarity and resistance coupled with pictures and experiences of law enforcement beating and kidnapping protesters by throwing them in unmarked vans (Nuyen, 2020) found their way into our classrooms. As we and many of our students participated in the 100 days of protests, we were all witnessing, if not living, the resistance to and violence of White supremacy we were studying. Concurrently, we were all living through a global pandemic.

As the global pandemic necessitated a rapid pivot from in-person classes to the (remote) Zoom platform, it is an understatement to note that our pedagogical approaches to the course content and current events felt experimental. We were in people's homes through Zoom, teaching personal and emotional content remotely for the first time. Many students were also learning remotely for the first time. We saw the students' children, pets, partners, wall art, and so much more, revealing certain intimacies. We both experienced enduring vulnerability through the process of teaching from our living rooms with our own children, pets, and partners only barely off the screen.

Journal of the Scholarship of Teaching and Learning, Vol. 21, No. 4, December 2021. josotl.indiana.edu 
The disembodied and somewhat intimate teaching-and-learning environment required patience, experimentation, and solid anchors amid a moment of profound instability. Our teaching anchor, our home base and touchstone amid the chaos and disruption, was an embrace of praxis. Consequently, we draw on feminist activist scholarship (Sudbury \& Okazawa-Rey, 2009), defined as "the production of knowledge and pedagogical practices through active engagements with, and in the service of, progressive social movements" (p. 3), to discuss and make sense of our pedagogy during this time. We engage in this reflexive praxis in the spirit of critical social work pedagogies (Mandell, 2007; Margolin, 1997; Morely et al., 2021; Rossiter, 2005) and with the intention to archive teaching against White supremacy within a particularly fraught, explosive, chaotic, and unprecedented moment in history. We find value in this archiving as an activity aligned with our feminist, antiracist commitments to social justice and social change, intended to support "skilling for activism" (Ashton, 2017). To this end, we have identified four teaching practices that helped us navigate this experimental and tumultuous time: (1) remembering for the future, (2) attending to collective grief and rage, (3) bringing the streets into the classroom, and (4) repurposing the classroom for social transformation.

\section{Remembering for the Future}

In her book Against Purity, Alexis Shotwell leans on Dunbar-Ortiz's (2008) concept of "unforgetting" and writes about remembering for the future, that is, remembering that the past has disproportionately harmed and benefited us, and how, so that we can acknowledge and be accountable for our complex interdependence (Maree-Brown, 2017; Shotwell, 2016) in service of creating a different future. In this social justice course, remembering for the future involved teaching Oregon's history of White supremacy and Black exclusion and teaching it in a manner that explicitly mapped the connections between the past and the present. Having taught this course before, we have found it is not uncommon for the students in our classes to be largely unaware that Oregon was established as a "white utopia" (Imarisha as cited in Camhi, 2020). Even those born in Oregon did not know that Oregon was founded as a White-only state with a range of Black exclusion laws. The nightly local BLM protests during the spring, summer, and fall of 2020 helped facilitate the collective process of unforgetting this history through classroom lectures, discussions, Zoom chats, journal writing, office hours, and individual communications. Learning about Oregon's racist history while witnessing Oregon's racist present unfold in the streets of Portland served as an act of collective remembering for the future, as the learning for the first time interrupts and resists epistemological ignorance (Mills, 2007) and whitewashing.

A challenge we experienced (and not for the first time) in remembering for the future revolved around how to teach about White supremacy without centering Whiteness because of White students' "big feelings" (DiAngelo, 2011) and frequent need to "race to innocence" (Razack, 1998). The predominance of White students in our social work classrooms means that White angst and discomfort around issues of Whiteness and racism are present and often activated through content and discussions. Although we recognize and value White students' emotional and psychological responses and experiences associated with remembering for the future, we often struggle with how to support and validate White students while motivating them to navigate their experiences in a way that does not recenter their learning at the expense of the BIPOC students' learning. We do not have any prescriptive advice for how to navigate such complexity and tension in the classroom, but we offer what we consider harm reduction teaching strategies that helped us: (1) use affinity breakout groups, (2) facilitate silent stream-of-consciousness writing during class time when White feelings and tears began to take up a lot of space, (3) teach reflective listening as a tool to manage reactivity in the classroom, (4) remind students to attend to how much space they take up when sharing, to leave room for those who may be more reluctant or less quick to share, (5) invite students to use the chat function

Journal of the Scholarship of Teaching and Learning, Vol. 21, No. 4, December 2021. josotl.indiana.edu 
as a means of encouraging more participation, (6) discuss the ways people are born into historical and contemporary contexts not of their own making, and that we all share in the responsibility for changing, and (7) move to talk about the what of the issue/situation, not the who.

\section{Attending to Collective Grief and Rage}

Although program directors encouraged us to limit the amount of time on Zoom (each class was scheduled for $2 \mathrm{hr}$ and $50 \mathrm{~min}$ ), students ultimately preferred to be remotely present for close to $3 \mathrm{hr}$ each week, rather than the planned $90 \mathrm{~min}$ on Zoom and $90 \mathrm{~min}$ of self-paced structured, online, asynchronous learning. Students desired a space where they could hear and be heard, support and get support, and metabolize the moment in a collaborative setting. They longed for a togetherness, even if it was oddly disconnected, fractured, and intimate through virtual spaces.

Given the pressure-cooker context of a national uprising and global pandemic, everyone's feelings were particularly acute throughout the term. Students, faculty, and staff were grieving the loss of loved ones, jobs, internships, joy, in-person learning, social norms, human connection, and faith in the U.S. democracy. Rage was also present as a reaction to the disproportionate impact of the pandemic on BIPOC and poor people resulting from structural racism and classism. Thus, teaching during the fall term of 2020 felt like surfing ever-expanding concentric waves of grief and rage. So much loss. We fumbled and experimented with ways to attend to this grief as part of the teaching and learning and latched on to Judith Butler's words about collective grief in an interview (Yancy, 2020):

A purely private form of mourning is possible but cannot assuage the cry that wants the world to bear witness to the loss. And with public losses of this magnitude and quick succession, there are political questions that are linked with the demand for public mourning: Why were health facilities so badly underfunded and unprepared? Why did the president disband the committee tasked with preparing for pandemics of this kind? Why are there not enough beds or ventilators? Why are Black people, incarcerated people, and migrants more at risk of dying than those who have been afforded decent health care for years? All these lost lives are grievable, which means that they are lives worthy of acknowledgment, equal in value to every other life, a value that cannot be calculated.

Acknowledging that grieving is personal, political, and cultural, we committed to creating space for grief in the "classroom." We aimed to normalize the grief, even invite it in. We named our own grief and that of our families and communities. We organized small breakout discussions to share and talk about grief. We shared poems and music. We invited students to acknowledge and write about grief in their weekly reading syntheses. We supported students to meet outside of virtual class time. Two of our three cohorts met once a week outside of class time, mostly to build community and support. These students also set up a WhatsApp group chat to reach out to each other throughout the term, and we offered additional drop-in/office hours. This praxis helped blur and complicate the student-instructor binary such that sharing and being with our collective grief made us all learners and teachers simultaneously. We were building a collective capacity for facing grief.

\section{Bringing the Streets Into the Classroom}

Togetherness was an experience we sought to engender in our classrooms for understanding the cultural moment. As we looked at Portland and the U.S. streets at large, we explored images of togetherness and solidarity. We saw no way to disentangle the social uprisings from students' daily lives, nor ours. The destruction of some of the material manifestations of White supremacy (cop cars,

Journal of the Scholarship of Teaching and Learning, Vol. 21, No. 4, December 2021. josotl.indiana.edu 
courthouses, corporations, etc.) demonstrated human capacities to actualize collective strength and power. Every burnt cop car, smashed window, and piece of clothing liberated from a chain store was a break with daily norms that tacitly reinforce White supremacist structures of power. We intentionally presented some of the more militant imagery from the uprisings to encourage students to question rampant binaries, including "violent/nonviolent," "legal/illegal," and "private/public property." We troubled the hegemonic conceptualizations of these terms to make visible the ways they were racially coded within the media. We then helped students trace how these terms were weaponized against demonstrators to quell the uprising and police people's righteous anger.

Further, these dynamic images of resistance functioned as examples we applied in our daily lives. We asked students to consider how the norms of their field placements, relationship structures, and thought patterns reflect the White supremacist culture from which they arise. We thought through how we might break with and trouble what remains unquestioned in our worlds. As students explored and deconstructed certain discourses explaining the uprisings, they came to understand the intrinsic relationship between White supremacy and normativity. They became aware that the status quo is a tacit perpetuator of White supremacy, and it often requires a rupture with social norms for one's needs to be met and voice to be heard.

We nudged students to consider their locations within dispersed and overlapping networks of power that control and encourage hegemonic forms of behavior. Insofar as bodies are constructed by discourse and structures (Foucault, 1983), reorienting students to power as ability and potentiality is central to resisting White supremacy. Foundational to any attack on White supremacy is acknowledging that one has the power to resist, subvert, and do something different. For BIPOC students, this is frequently a given, as existence itself is often resistance. Despite possessing disproportionate institutional privilege and power, White students often appeared to be waiting for permission to be outraged and engaged. It often felt as though they did not want to be seen as coopting the moment or taking the focus and attention away from their BIPOC peers who were deeply impacted in ways they were not. Fortunately, the countless daily examples of attack and resistance through the racial uprising provided a range of opportunities for all students to explore their commitments to abolishing White supremacy. The multiple opportunities to engage in activism on the streets engendered hope and supported students' sense of agency and efficacy, particularly those new to activism.

Two questions remained essential to us throughout the quarter: What are the effects on students' sense of agency when they can watch and participate in real time with those actively fighting against White supremacy? Second, how does this agency translate to one's capacity to outmaneuver White supremacist logic in the current time? Students witnessed people in Minneapolis organizing protests without permits and joining together organically, with multiple entry points for participation. The uprising was diverse in its tactics and presented infinite ways to resist and attack White supremacy (e.g., becoming a street medic, serving food, standing off with cops, banner drops, etc.). As students' sense of possibility and agency increased by witnessing and discussing organizing in the city and around the country, they began to understand and imagine the options they might engage in to resist White supremacy through mass-scale demonstrations, their daily speech acts, interactions, and thought processes. We explored agency, resistance, and survival questions using students' local and embodied knowledge-centering students of color and other marginalized students. Undoubtedly, students' racialized positionalities tended to drastically impact their interpretations of these questions. However, BIPOC students tended to live resistance daily and could look to their own and generations of resistance, for example. To be sure, BIPOC people have been honing the skills to outmaneuver and survive White supremacy their entire lives.

Conversely, many White students are learning about White supremacy for the first time and are uncertain, although most often willing to enter the struggle for its eradication. White students can

Journal of the Scholarship of Teaching and Learning, Vol. 21, No. 4, December 2021. josotl.indiana.edu 
choose the extent to which they want to participate in uprisings, so we aimed to guide White students to realize that they have "skin in the game" in the struggle against White supremacy (Ward, 2017). To do that, we had to conceptualize Whiteness as a lived experience conveying extreme forms of social privilege (e.g., being able to live without the omnipresent fear of racialized murder) and as a structural/institutional phenomenon (e.g., White supremacy) moving through and around bodies. We asked all students to consider how discourses of race position us socially, and-candidly-we collectively explored how to weaponize our privileged identities (e.g., social worker, college student, housed, etc.) against logics of White supremacy. To our excitement, the students began to see the privilege that accompanies their position as social workers as an entry point for resistance, not just a dominant social position to be outright rejected. Within the classroom, we exchanged stories of times we have used our power as social workers to interrupt how this professional location entices us to maintain systems of White supremacy. Students discussed the paradoxes inherent in the role of social workers as simultaneous change agents and agents of social control. It became clear to us all that any perpetuation of the status quo-particularly through the role of social worker-is antithetical to a disruption of White supremacy.

Our goal for all students, but White students specifically, was to consider that resisting White supremacy is possible in the streets and in their/our daily practices of living and thinking. Conceptualizing power as ubiquitous and as a diffuse social process was/is key to this lesson. We relied heavily on Foucault's notions of power to help us all think of power as relational, as potential, as knowledge, and as existing everywhere (Foucault, 1978). Framing power as a force that moves through people and discourses facilitated explorations of our word choices and behaviors, and consequently, our agency to challenge oppressive conditions/discourses. Examples from the movement for Black lives gave us real-time examples of how to combat White supremacy, both ideologically and tangibly at the localized and individualized level. Simultaneously, we saw collaborations and affinities across social categorization that offered examples of solidarity, and the building of nonhierarchical, responsive infrastructures, outside of social work and nongovernmental organizations.

For many students, this was the first time they witnessed mutual aid, transformative struggle, and camaraderie outside of formal organizations and legislative processes. Consequently, students were able to conceive of themselves, of people like them, as change agents. They began to recognize that resistance to White supremacy requires constant diligence and critical engagement with one's words and actions, driven by the optimistic (yet realistic) hope that everything can change and repurposing our social landscapes is possible. They began to reject and reconsider the normative discourses that delineate the boundaries of the acceptable within the classroom, their internships, and protest engagements. Many of them began to push beyond professional expectations by exemplifying socially just worlds in the here and now. For us, this looked like repurposing the classroom by uprooting the discourses within it that seek to maintain oppressive social relations, and from this, we all felt new worlds emerge.

\section{Repurposing the Classroom}

Repurposing (Wahab, Bhyuan, Park, 2018) is one of the concepts that resonated most with students. Collectively witnessing city streets repurposed for massive demonstrations, homeless encampments, dance clubs, free food pantries, and autonomous zones made the concept tangible and possible. With this as our backdrop, we attempted to exemplify repurposing as a tool against White supremacy within our classrooms. Repurposing is an agentic and collective process that creates a new purpose for the classroom. The classroom holds various unspoken discourses that, if left unchallenged, students and

Journal of the Scholarship of Teaching and Learning, Vol. 21, No. 4, December 2021. josotl.indiana.edu 
teachers alike can and do unquestioningly inhabit. The unexamined classroom can entice us to take up positions of authority (instructor) and positions of passivity and consumption (students).

There is no place of innocence within the hierarchy foundational to college classrooms. There is however, the instructor's willingness to remain diligent and confrontational of the insidious ways hierarchical authority encourages behavioral expectations. Repurposing requires a willingness to experiment. It is a tactic that rewires and reconfigures a structure already in place, in this case, the classroom. We use the word "tactic" intentionally because tactics are the context-specific, shifting, and subjective ways to meet the moment. Conversely, strategies connote long-term planning, with an emphasis on future-oriented outcomes. Long-term planning felt inefficient given the ever-shifting context of the fall 2020 quarter. To repurpose our classrooms, we used many tactics but relied significantly on (1) connection and power, (2) interminable experimentation, and (3) theory as resistance.

Connection and power. Cultivating meaningful relationships with students is foundational to repurposing the classroom. In some ways, we aligned with the economic and emotional stress that students were experiencing. Like our students, we were exhausted. We spoke openly about our desire to create a classroom where emotion was allowed, understood, and discussed collectively. We demonstrated the productive possibilities of power by showing how individuals can use power to disrupt authority. We worked with the students to untangle what is easy to conflate: power and authority. To do this, we spoke candidly about the authority implicit in our roles as instructors. We often acknowledged that we are the face of and benefit from an institution steeped in White supremacy, built on stolen land, and frequently engaged in dehumanizing tendencies. Being honest about one's commitments, limitations, and privileges can demystify the instructor's role and create a space where students feel comfortable to share openly too and to question the instructor's authority that is often taken for granted in the classroom. Disrupting some hierarchical authority is paramount to building solidarity with students and fostering the connection needed to repurpose a classroom space collectively.

Interminable experimentation. The repurposed classroom opens space for experimentation, vulnerability, and practice. Throughout fall 2020, we attempted to foster a classroom context that moved students away from seeking expertise in social justice strategies and toward thoughtful experimentation in them. We encouraged students to think beyond the discourses of social justice and freedom in favor of a reconceptualization of these terms that factors in context, social location, and unique interpretations of them. The classroom became a sounding board for student-driven discussions on the unique ways each person was living out these concepts both in the streets and within social worker settings. From this, social justice became a livable and actual reality rather than a future-oriented goal. Our individual and collective practices in liberation, or more socially just worlds, were understood as open-ended projects rather than course concepts accompanied by prescriptive behaviors. The classroom was a playground of potentiality, a space to bring in and reflect upon one's unique interpretation of and actions to abolish White supremacy.

We tried to create a container in which students could practice resisting White supremacy and other forms of oppression. We asked students to move beyond expectations and performances of expertise by considering how their lived experiences informed their attacks on White supremacy and how this is messy, emerging, and often only clear after one has engaged in active confrontations of White supremacy. Looking at the real-world examples from the streets in Portland and the rest of the country, we used the language of revolt, reconceptualization, and resistance. We used models from students' daily lives, internships, and engagement in street protests; we asked them to notice and name the ideas and concepts we were learning. We also asked students to apply, practice, and put the ideas and concepts they learned into motion. From this, students began seeing the potential of daily resistance both in the classroom and at their internships. They often spoke of the revolutionary

Journal of the Scholarship of Teaching and Learning, Vol. 21, No. 4, December 2021. josotl.indiana.edu 
potential of everyday resistance. They cited examples of deconstructing agency policies at their internships, bringing these insights to their field instructors, and bringing the radical vulnerability and authenticity of their classroom experiences into their field placements. From week to week, we all attempted to live out our antiracist ideals and put into action the insights gleaned from our protest engagements and classroom dialogues. This action-reflection-action process with the students was ongoing throughout the quarter. Encouraging students to think of praxis asunedning allowed for critical reflection and error and gave students the space to move from guilt and fear (e.g., purity) toward experimentation, willingness, and bravery.

Theory as resistance. Poststructuralism is a theoretical framework that allows for such experimentation. Built into this is epistemology is a rejection of binaries, determinism, power in the repressive, and singular truths (Foucault, 1978). Part of poststructuralism's utility, particularly in a moment of social rupture, is an analytic framework for an ongoing deconstruction of previously takenfor-granted truths about our worlds (Derrida, 1998). Poststructuralism and critical theories represent the course's epistemological foundation and led us to ask: What does social work knowledge do, and why are some ways of knowing privileged and legitimized while others remain marginalized? Critical epistemologies attend to such questions by noticing discontinuities in what is presented as legitimate knowledge, opening space for student voices and experiences, particularly the voices of BIPOC students. Through our explorations of subjugated knowledges via our lived experiences, we cultivated a theoretical space to imagine new possibilities and new ways of being. This followed the poststructuralist acknowledgment that there are possibilities of resistance, freedom, and selfreinvention even within oppressive social arrangements (Foucault, 1978). Many students felt this intuitively and for others, learning that resistance strategies can start at the individual level felt novel, liberating, and exciting.

The repurposed classroom has many experts, leaders, guides, and accomplices. In the repurposed classroom, we are all theorists-experts in our own lives making sense and meaning of our worlds. During the first 2 weeks of the quarter, we invited students to discuss their lived experiences with the theoretical work we engaged in in the classroom. We also asked students to consider themselves as people creating theory, because everyone has an approach to their work and beliefs, values, and assumptions that help them make meaning of the world they live in. Ultimately, we asked them to "theorize themselves into existence" (hooks, 1994). In the context of uprising, theory enlivened the repurposed classroom.

\section{Final Thoughts: "To change everything, start anywhere!" (CrimethInc., 2018)}

Although the fires in the streets have died down, it remains critical that we fan the flames of the uprising in our hearts. To that end, we intend to maintain the immediacy of our confrontations with White supremacy and carry with us the adaptations, accommodations, and lessons learned into our practices of teaching and living. The rebellious, uncertain, and urgent moment gifted an opportunity to embrace, expand, and situate the students' (and our) learning directly within this social rupture. From this, we have learned that cultivating students' sense of agency can occur by directly linking course content to examples from the uprising and can ground their everyday practices of resistance within broader social movements. In addition, we have learned that explorations of the actions of those engaged in social struggles can foster bravery in one's personal and professional lives (a no-lessrevolutionary space to enact change). Finally, we have learned that the fight against White supremacy can happen anywhere and happens primarily through a rejection of what is to carve out what can be.

We assume the classroom to be a microcosm of society. As such, the experimentations in freedom and the radical dialogues that occurred within its confines carry exciting implications for transformation on a grander scale. The year 2020 showed us all that we can do things differently, that

Journal of the Scholarship of Teaching and Learning, Vol. 21, No. 4, December 2021. josotl.indiana.edu 
we hold power to disrupt traditions. Change is not only possible, it is necessary! Daily resistance against White supremacy can, and must, continue inside and outside the classroom. White supremacy is a living phenomenon with deadly consequences, and its tentacles and technologies are varied and insidious. Each of us has a responsibility to unearth its toxic presence and attack it from where we stand. Let us remember the George Floyd uprisings, learn from them, and integrate them into our own "revolution[s] of everyday life" (Vaneigem, 1994).

\section{References}

Ashton, J. (2017). Feminist archiving [a manifesto continued]: Skilling for activism and organising. Australian Feminist Studies, 32(91-92), 126-149. https://doi.org/10.1080/08164649.2017.1357010

Brown, A. M. (2017). Emergent strategy: shaping change, changing worlds. Chico, CA: AK Press.

Brown, J. H. (1892). Brown's political history of Oregon. Provisional government. Treaties, conventions, and diplomatic correspondence on the boundary question. W.B. Allen.

Brulliard, K., Criag, T., Hauslohner, A, Wootson, C., Hawkins, D., Wilson, S., Witte, G., Knowles, H., \& Kornfield, M. (2020, September 27). Far-right group draws hundreds to Portland as city seeks to prevent clashes with left-wing activists. The $W$ ashington Post. https://www.washingtonpost.com/nation/2020/09/26/protests-portland-live-updates/

Burke, L. N. N., \& Jeffries, J. L. (2016). The Portland Black Panthers: Empowering Albina and remaking a city. University of Washington Press.

Camhi, T. (2020, June 9). A racist history shows why Oregon is still so white. Oregon Public Broadcasting. https://www.opb.org/news/article/oregon-white-history-racist-foundations-blackexclusion-laws/

CrimethInc. (2018). To change everything: An anarchist appeal. CrimethInc. https://crimethinc.com/zines/to-change-everything

Darby, J. Perini, J., \& Yanke, E. (Directors). (2015). Arresting power: Resisting police violence in Portland, Oregon [Film]. Collective Eye Films.

Derrida, J. (1998). Of grammatology (Corrected ed.). Johns Hopkins University Press.

DiAngelo, R. (2011). White fragility. The International Journal of Critical Pedagogy, 3(3), 54-70.

Dunbar-Ortiz, R. (2008). The opposite of truth is forgetting: An interview with Roxanne DunbarOrtiz by Chris Dixon. Uppin the Anti 6 (May), 47-58.

Foucault, M. (1978). The history of sexuality. Random House.

Foucault, M. (1983). On the genealogy of ethics: an overview of work in progress. In H. L. Dreyfus \& P. Rabinow (Eds.), Michel Foucault: beyond structuralism and bermeneutics (pp. 229-252). University of Chicago Press.

Freire, P. (1970). Pedagogy of the oppressed. Herder and Herder.

hooks, b. (1994). Teaching to transgress: education as the practice of freedom. Routledge.

Imarisha, W. (2020, October 26). Essay on Oregon Black bistory \& Alonzo Tucker. https://www.walidah.com/blog/2020/10/26/essay-on-oregon-black-history-amp-alonzotucker

McClintock, Anne, 1954-. (1995). Imperial leather : race, gender, and sexuality in the colonial contest. New York :Routledge/

Mandell, D. (2007). Revisiting the use of self: Questioning professional identities. Canadian Scholars Press. Margolin, L. (1997). Under the cover of kindness: The invention of social work. University Press of Virginia.

Journal of the Scholarship of Teaching and Learning, Vol. 21, No. 4, December 2021. josotl.indiana.edu 
Michel, C. (2017, June 30). How liberal Portland became America's most politically violent city. Politico. https://www.politico.com/magazine/story/2017/06/30/how-liberal-portlandbecame-americas-most-politically-violent-city-215322/

Mills, C. W. (2007). White ignorance. In S. Sullivan \& N. Tuana (Eds.), Race and epistemologies of ignorance (pp. 11-38). State University of New York Press.

Morely, C., Ablett, P., Nobel, C., \& Cowden, S. (2021). The Routledge handbook for critical pedagogies for social work. Routledge.

MSW Program. (2020). Black Lives Matter — call to action. Portland State University, School of Social Work, MSW Program Call to Action adopted June 4, 2020.

Nuyen, S. (2020, July 17). Federal officers use unmarked vehicles to grab people in Portland, DHS confirms. National Public Radio. https://www.npr.org/2020/07/17/892277592/federal-officers-useunmarked-vehicles-to-grab-protesters-in-portland

Oregon State Archives. (n.d.). Transcribed 1857 Oregon Constitution. https://sos.oregon.gov/archives/exhibits/constitution/Documents/transcribed-1857oregon-constitution.pdf

Razack, S. (1998). The race to innocence: Confronting hierarchical relations among women. Journal of Gender Race and Justice, 1, p. 335-352. https:// scholarship.law.umn.edu/faculty articles/274

Rossiter, A. (2005). Discourse analysis in critical social work. Critical Social Work, 6(1). Retrieved from http://www.criticalsocialwork.com/.

Semuels, A. (2016, July 22). The racist history of Portland, the Whitest city in America. The Atlantic. https://www.theatlantic.com/business/archive/2016/07/racist-history-portland/492035/

Serwer, A. (2020, October). The new reconstruction. The Atlantic. https://www.theatlantic.com/magazine/archive/2020/10/the-next-reconstruction/615475/

Shotwell, A. (2016). Against purity: Living ethically in compromised times. University of Minnesota Press.

Sudbury, J., \& Okazawa-Rey, M. (2009). Activist scholarship: Antiracism, feminism, and social change. Paradigm Publishers.

United States Census Bureau. (2020, August 23). Quick facts, Portland city, Oregon. https://www.census.gov/quickfacts/portlandcityoregon

Vaneigem, R. (1994). The revolution of everyday life (2nd rev. ed.). Rebel Press; Left Bank Books.

Vercammen, P., \& Yan, H. (2017, June 1). Portland's liberal image tempered by history as 'Skinhead City.' CNN. https://www.cnn.com/2017/05/31/us/portland-white-supremacyhistory/index.html

Wahab, S., Bhyuan, R., \& Park, Y. (2018). Feeding the scyborgs in social work: Enduring commitments that sustain. Affilia: Women and Social Work, 33(3), 281-285. https://doi.org/10.1177/0886109918786141

Ward, E. (2017). Skin in the game: How antisemitism animates white nationalism. Political Research Associates. https://www.politicalresearch.org/2017/06/29/skin-in-the-game-howantisemitism-animates-white-nationalism.

Wilson, J. (2020, July 23). Portland protests: Federal agents' actions draw city into a national debate. The Guardian. https://www.theguardian.com/us-news/2020/jul/23/portland-protestspolicing-trump-administration

Yancy, G. (2020, April 20). Judith Butler: Mourning is a political act amid the pandemic and its disparities. Truth Out. https://truthout.org/?s=judith+butler 